\title{
ABO blood group type does not influence the level of SARS-CoV-2 antibody response in convalescent plasma donors
}

Klemen Žiberna ${ }^{1}$, Katerina Jazbec ${ }^{1}$, Mojca Jež ${ }^{1}$, Polonca Mali ${ }^{1}$, Urška Rahne Potokar ${ }^{1}$, Primož Rožman $^{1 *}$

Blood Transfusion Centre of Slovenia, Šlajmerjeva 6, 1000 Ljubljana, Slovenia

* corresponding author: primoz.rozman@ztm.si

\begin{abstract}
The association of ABO blood group types with the COVID-19 disease has been confirmed by several studies, with the blood group A-type patients being more susceptible and prone to more severe clinical course of disease. Similarly, some authors explored the association of ABO-types and the levels of anti-SARS-CoV-2 antibodies in convalescents. The recent reports mostly support a theory that non-O blood group convalescents present with higher levels of anti-SARS-CoV-2 antibodies. Since these findings were based on small convalescent cohorts, we quantified the anti-SARS-CoV-2 antibodiy levels in four larger cohorts of total 3185 convalescent plasma donors with three commercial serological tests and one standard neutralizing antibody test. The majority of donors had undergone a mild form of disease and the median time of sampling was 66 days after the onset of COVID-19 symptoms. None of the antibody quantitation methods showed an association of the ABO blood group types with the level of anti-SARS-CoV-2 antibodies. The same result is evident in the group of vaccinated individuals $(n=370)$ as well as in the groups stratified into three post-COVID-19 periods $(0-60,60-120$, and 120-180 days). In conclusion we can state that the $A B O$ blood group type does not influence the level of SARS-CoV-2 antibody response in COVID-19 convalescent plasma donors.
\end{abstract}

\section{Keywords}

COVID-19 convalescent plasma; plasma donors; humoral immunity, SARS-CoV-2 antibodies; vaccination 
medRxiv preprint doi: https://doi.org/10.1101/2021.10.19.21265195; this version posted October 26, 2021. The copyright holder for this preprint (which was not certified by peer review) is the author/funder, who has granted medRxiv a license to display the preprint in perpetuity.

It is made available under a CC-BY-ND 4.0 International license .

\section{Background}

$A B O$ histo-blood group antigens are expressed on blood cells, some other tissues, and in the body fluids. Already in the early studies of SARS-CoV-2 pandemic, the association of ABO blood group type with the SARS-CoV-2 infection has been noticed, where the blood group A was associated with an increased risk of disease compared to the blood group $O$ that was associated with a decreased risk for severe COVID-19 illness ${ }^{1,2}$. Although certain studies failed to confirm such association ${ }^{3,4}$, several large cohort studies ${ }^{5,6}$, reviews and meta-analyses ${ }^{7-10}$ confirmed that the individuals with blood group A are more susceptible and those with blood group $\mathrm{O}$ are less susceptible for COVID-19.

In the absence of specific anti-viral remedies, hyperimmune COVID-19 convalescent plasma (CCP) containing high titers of anti-SARS-CoV-2 antibodies (Abs) has been proposed as therapeutic modality early in the pandemic and it has been widely clinically used ${ }^{11-14}$. Because only CCP units with a high titer of anti-SARS-CoV-2 antibodies are recommended for treatment ${ }^{15}$, researchers have tried to define the factors affecting the quantity of anti- SARS-CoV-2 Abs in the convalescents. The correlation of antibody (Ab) levels in CCP donors with their ABO-type has been studied by several authors, who reported conflicting results mostly based on limited cohorts of COVID-19 convalescents. For instance, Li et al. reported that in 49 CCP convalescents, the levels of spike receptor binding domain (S-RBD)-specific and nucleocapsid (N)specific lgG Abs had no significant correlation to their ABO-type ${ }^{16}$. Similarly, Körper et al. found no correlation between ABO-types and titers of neutralizing Abs in 144 CCP donors ${ }^{17}$, and Wendel et al. reported no such correlation in 78 CCP donors ${ }^{18}$. On the other hand, Madariaga et al. found in 103 CCP donors that AB-type donors had higher anti-RBD and antispike $A b$ levels compared to O-type donors ${ }^{19}$. De Freitas Dutra et al. reported in 268 donors and 162 patients, that O-type individuals had lower SARS-CoV-2 Ab titers than A and AB individuals ${ }^{20}$. Bloch et al. reported that in 202 CCP donors there were no significant differences in anti-spike IgA or anti-spike IgG Ab titers by $A B O$ blood group, but that significantly more Btype individuals presented with a high neutralization $A b$ titer $(\geq 1: 160)$ compared to O-type and A-type donors ${ }^{21}$. In a recent paper Hayes et al. reported that in 2320 -type convalescents they found significantly lower levels of SARS-CoV-2 IgG Abs compared to A-type individuals ${ }^{22}$.

Based on these ambiguities we decided to clarify this question by exploring the association of ABO-type with the concentration of anti-SARS-CoV- 2 antibodies and neutralizing antibodies in a much larger cohort of 3185 CCP donors.

\section{Methods}

\section{Convalescent plasma donors}

The first donations from 3185 CCP donors with a history of polymerase chain reaction (PCR) confirmed SARS-CoV-2 infection in nasopharyngeal swab were included and collected between June 2020 and August 2021. Standard eligibility criteria for volunteer blood donors were used. Out of these, $90 \%$ participants reported having mild symptoms and $10 \%$ reported moderate to 
medRxiv preprint doi: https://doi.org/10.1101/2021.10.19.21265195; this version posted October 26, 2021. The copyright holder for this preprint (which was not certified by peer review) is the author/funder, who has granted medRxiv a license to display the preprint in perpetuity.

It is made available under a CC-BY-ND 4.0 International license .

severe symptoms with 6 participants requiring hospital treatment. The median (IQR) duration between the start of COVID-19 symptoms and CCP donation was 66 (45-114) days.

The $A B O$ blood group distribution in the $3185 \mathrm{CPP}$ donors was $40.5 \% \mathrm{~A}, 37.9 \% \mathrm{O}, 14.9 \% \mathrm{~B}$, and $6.8 \% A B$, which matches our 2017 data for general blood donor population ${ }^{23}$. Since the vaccination has been implemented after January 2021, 370 convalescent donors have also received the vaccination before their first CPP collection. Basic donor information is presented in Table 1.

Table 1. Basic demographic factors, results of serology tests, and vaccination status in COVID-19 convalescent plasma donors with different ABO blood group types

\begin{tabular}{|c|c|c|c|c|c|}
\hline & $\begin{array}{c}\text { Group } 0 \\
(\mathrm{~N}=1206) \\
37.9 \%)\end{array}$ & $\begin{array}{c}\text { Group A } \\
\text { ( } N=1289) \\
40.5 \%\end{array}$ & $\begin{array}{c}\text { Group B } \\
(\mathrm{N}=475) \\
14.9 \%\end{array}$ & $\begin{array}{c}\text { Group AB } \\
(\mathrm{N}=215) \\
6.8 \%\end{array}$ & p-value \\
\hline Gender - female & $\begin{array}{c}423(35.1 \%) \\
(N=1206)\end{array}$ & $\begin{array}{c}447(34.7 \%) \\
(N=1289)\end{array}$ & $\begin{array}{c}169(35.6 \%) \\
(N=475)\end{array}$ & $\begin{array}{c}71(33.0 \%) \\
(N=215)\end{array}$ & 0.925 \\
\hline Age (years) & $\begin{array}{c}41.94 \pm 0.32 \\
(N=1206)\end{array}$ & $\begin{array}{c}41.33 \pm 0.30 \\
(N=1289)\end{array}$ & $\begin{array}{c}42.29 \pm 0.52 \\
(N=475)\end{array}$ & $\begin{array}{c}42.15 \pm 0.73 \\
(N=215)\end{array}$ & 0.300 \\
\hline Body weight (kg) & $\begin{array}{c}83.97 \pm 0.49 \\
(N=1050)\end{array}$ & $\begin{array}{c}84.41 \pm 0.49 \\
(N=1124)\end{array}$ & $\begin{array}{c}83.99 \pm 0.8 \\
(N=420)\end{array}$ & $\begin{array}{c}84.39 \pm 1.22 \\
(N=182)\end{array}$ & 0.923 \\
\hline $\begin{array}{l}\text { Days after start of COVID-19 } \\
\text { symptoms }\end{array}$ & $\begin{array}{c}65 \\
{[45-110]} \\
(N=1116)\end{array}$ & $\begin{array}{c}66 \\
{[45-115]} \\
(N=1177)\end{array}$ & $\begin{array}{c}66 \\
{[46-120]} \\
(N=438)\end{array}$ & $\begin{array}{c}73 \\
{[43-115]} \\
(N=198)\end{array}$ & 0.838 \\
\hline $\begin{array}{l}\text { Wantai semi-quantitative } \\
\text { SARS-CoV-2 Ab test (index S/C }\end{array}$ & $\begin{array}{c}15.82 \\
{[8.29-18.95]} \\
(N=158)\end{array}$ & $\begin{array}{c}17.71 \\
{[8.02-19.19]} \\
(N=178)\end{array}$ & $\begin{array}{c}17.84 \\
{[11.09-19.47]} \\
(N=67)\end{array}$ & $\begin{array}{c}18.59 \\
{[9.61-19.71]} \\
(N=31)\end{array}$ & 0.224 \\
\hline $\begin{array}{l}\text { Abbott semi-quantitative SAR } \\
\text { CoV-2 Ab test (index S/C) }\end{array}$ & $\begin{array}{c}3.81 \\
{[1.90-5.71]} \\
(N=380)\end{array}$ & $\begin{array}{c}3.63 \\
{[1.84-5.89]} \\
(N=401)\end{array}$ & $\begin{array}{c}3.68 \\
{[1.92-5.87]} \\
(N=161)\end{array}$ & $\begin{array}{c}3.97 \\
{[1.3-5.72]} \\
(\mathrm{N}=77)\end{array}$ & 0.998 \\
\hline $\begin{array}{l}\text { Abbott quantitative SARS-CoV } \\
2 \text { Ab test }(\mathrm{AU} / \mathrm{ml})\end{array}$ & $\begin{array}{c}451 \\
{[194-1694]} \\
(N=994)\end{array}$ & $\begin{array}{c}558 \\
{[212-2160]} \\
(N=1047)\end{array}$ & $\begin{array}{c}510 \\
{[221-2751]} \\
(N=355)\end{array}$ & $\begin{array}{c}472 \\
{[169-1953]} \\
(N=164)\end{array}$ & 0.094 \\
\hline $\begin{array}{l}\text { Neutralization test } \\
\text { (titer) }\end{array}$ & $\begin{array}{c}80 \\
{[40-320]} \\
(N=417)\end{array}$ & $\begin{array}{c}80 \\
{[20-320]} \\
(N=558)\end{array}$ & $\begin{array}{c}80 \\
{[20-320]} \\
(N=223)\end{array}$ & $\begin{array}{c}80 \\
{[20-320]} \\
(N=104)\end{array}$ & 0.414 \\
\hline $\begin{array}{l}\text { Nr. of units with high neutrali- } \\
\text { zation test values }(>160)\end{array}$ & $\begin{array}{c}159(38.1 \%) \\
(N=417)\end{array}$ & $\begin{array}{c}239(42.8 \%) \\
(N=558)\end{array}$ & $\begin{array}{c}87(39.0 \%) \\
(N=223)\end{array}$ & $\begin{array}{c}38(36.5 \%) \\
(N=104)\end{array}$ & 0.382 \\
\hline Vaccination & $126(10.4 \%)$ & $157(12.2 \%)$ & $64(13.5 \%)$ & $23(10.7 \%)$ & 0.287 \\
\hline
\end{tabular}

Legend: Data are presented as a mean and a standard error of mean (SEM) for normally distributed data, a median and an interquartile range (IQR) for non-parametric data, and as a count and a percentage for binary data. The statistical comparison between multiple groups was performed using oneway ANOVA test for normally distributed data, Kruskal-Wallis ANOVA test for non-parametric data, and Pearson's chi-squared test for binomial data.

*S/C, sample/cut-off; $A U$, arbitrary units 
medRxiv preprint doi: https://doi.org/10.1101/2021.10.19.21265195; this version posted October 26, 2021. The copyright holder for this preprint (which was not certified by peer review) is the author/funder, who has granted medRxiv a license to display the preprint in perpetuity.

It is made available under a CC-BY-ND 4.0 International license .

\section{Serology testing}

Two semi-quantitative and one quantitative serological tests were used to detect anti-SARSCoV-2 antibodies: i) Wantai SARS-CoV-2 Ab ELISA, an enzyme-linked immunosorbent assay for qualitative detection of total IgG and IgM antibodies to the RBD of SARS-CoV-2 spike protein that was performed on 434 samples; ii) Abbott SARS-CoV-2 IgG assay, a chemiluminescent microparticle assay (CMIA) for the qualitative detection of IgG Abs to the nucleocapsid protein that was performed on 1019 samples; and iii) Abbott SARS-CoV-2 IgG II Quant, second generation CMIA for quantitative determination of IgG Abs to the RBD of the S1 subunit of the SARSCoV-2 spike protein, including the neutralizing Abs that was performed on 2560 samples. All tests were performed according to the manufacturers' instructions.

For the neutralizing antibody testing, a standard live SARS-CoV-2 microneutralization assay was used $^{24}$. The assay read out was the cytopathic effect, where assay cut-off titer was <1:20. Neutralization test was performed on 1302 samples by the Institute of Microbiology and Immunology, Faculty of Medicine, University of Ljubljana.

\section{Results and Discussion}

The antibody analysis according to different $A B O$ blood group types is presented in Table 1. There were no statistically significant differences between the SARS-CoV-2 antibody levels in the different $A B O$-types regardless of which serological method was used.

Although the quantitative Abbott SARS-CoV-2 IgG II Quant test resulted in slightly higher titers in the A-type group ( $558 \mathrm{AU} / \mathrm{mL}$ ), the differences compared to other blood group types are not significant. The same dynamic is seen in the neutralization test titer values: there are no differences between the donors of different $A B O$ blood group types. The proportion of samples with high neutralization test values (titer $>160$ ) reveals no ABO-type related differences either.

If the cohort is divided into vaccinated $(n=370)$ and unvaccinated convalescents $(n=2815)$, the result is similar and no statistically significant differences are evident. However, average titers of IgG and neutralizing antibodies in the vaccinated groups were as expected significantly higher $(1: 1,280$ [1:640-11,280] vs. $1: 80$ [1:20-1:160], $p<0.001)$ in the neutralization tests, and $1: 12,200$ vs. $1: 380 \mathrm{AU} / \mathrm{mL}$ in the Abbott quantitative test (data not shown).

As there is a possibility that analysis of CCP donations in different period post infection would lead to different results, we analyzed antibody responses in unvaccinated CCP donors grouped by different donation periods after the onset of COVID-19 symptoms, which led to the same conclusion: there are no statistically significant differences between donors of different $A B O$ blood groups (see Table 2). 
medRxiv preprint doi: https://doi.org/10.1101/2021.10.19.21265195; this version posted October 26, 2021. The copyright holder for this preprint (which was not certified by peer review) is the author/funder, who has granted medRxiv a license to display the preprint in perpetuity.

It is made available under a CC-BY-ND 4.0 International license .

Table 2. Antibody response in unvaccinated CCP donors of different ABO-types according to the post-infection period as measured by quantitative and neutralization tests

\begin{tabular}{|c|c|c|c|c|c|}
\hline & 0 & A & B & $A B$ & p-valu \\
\hline \multicolumn{6}{|l|}{$\begin{array}{l}\text { Abbott quantitative } \\
\text { SARS-CoV-2 Ab test (AU/mL) }\end{array}$} \\
\hline $\begin{array}{l}0 \text { - } 60 \text { days after start of COVID-19 } \\
\text { symptoms }\end{array}$ & $\begin{array}{c}418.5 \\
{[187.0-968.8]} \\
(N=345)\end{array}$ & $\begin{array}{c}446.5 \\
{[189.4-1038.57} \\
(N=354)\end{array}$ & $\begin{array}{c}405.95 \\
{[204.7-848.15]} \\
(N=118)\end{array}$ & $\begin{array}{c}532.3 \\
{[166.02-1587.73} \\
(N=44)\end{array}$ & 0.995 \\
\hline \multirow[t]{2}{*}{$\begin{array}{l}60 \text { - } 120 \text { days after start of COVID- } \\
19 \text { symptoms }\end{array}$} & $\begin{array}{c}340.5 \\
{[165.8-825.77]} \\
(N=318)\end{array}$ & $\begin{array}{c}402.45 \\
{[192.6-908.15]} \\
(N=334)\end{array}$ & $\begin{array}{c}395.0 \\
{[170.25-963.65} \\
(N=103)\end{array}$ & $\begin{array}{c}357.15 \\
{[192.47-782.15]} \\
(N=58)\end{array}$ & 0.605 \\
\hline & $\begin{array}{c}279.0 \\
{[135.07-690.0]} \\
(N=110)\end{array}$ & $\begin{array}{c}421.5 \\
{[152.9-1161.3]} \\
(N=101)\end{array}$ & $\begin{array}{c}325.25 \\
{[138.12-694.1]} \\
(N=38)\end{array}$ & $\begin{array}{c}161.85 \\
{[107.42-405.35]} \\
(N=22)\end{array}$ & 0.145 \\
\hline \multicolumn{6}{|l|}{ Neutralization test (titer) } \\
\hline $\begin{array}{l}0-60 \text { days after onset of COVID-10 } \\
\text { symptoms }\end{array}$ & $\begin{array}{c}40.0 \\
{[20.0-160.0]} \\
(N=192)\end{array}$ & $\begin{array}{c}40.0 \\
{[20.0-160.0]} \\
(N=215)\end{array}$ & $\begin{array}{c}40.0 \\
{[0.0-80.0]} \\
(\mathrm{N}=97)\end{array}$ & $\begin{array}{c}40.0 \\
{[5.0-80.0]} \\
(N=50)\end{array}$ & 0.593 \\
\hline $\begin{array}{l}60 \text { - } 120 \text { days after onset of COVID } \\
19 \text { symptoms }\end{array}$ & $\begin{array}{c}60.0 \\
{[40.0-80.0]} \\
(N=96)\end{array}$ & $\begin{array}{c}40.0 \\
{[20.0-80.0]} \\
(N=128)\end{array}$ & $\begin{array}{c}80.0 \\
{[20.0-160.0]} \\
(N=52)\end{array}$ & $\begin{array}{c}40.0 \\
{[5.0-80.0]} \\
(N=22)\end{array}$ & 0.637 \\
\hline $\begin{array}{l}120-180 \text { days after onset of } \\
\text { COVID-19 symptoms }\end{array}$ & $\begin{array}{c}80.0 \\
{[20.0-80.0]} \\
(N=28)\end{array}$ & $\begin{array}{c}80.0 \\
{[20.0-160.0]} \\
(N=40)\end{array}$ & $\begin{array}{c}40.0 \\
{[20.0-80.0]} \\
(N=13)\end{array}$ & $\begin{array}{c}30.0 \\
{[15.0-50.0]} \\
(N=4)\end{array}$ & 0.586 \\
\hline
\end{tabular}

Legend: Data are presented as a median and an interquartile range (IQR) and the statistical comparison between groups was performed using Kruskal-Wallis ANOVA test. AU, arbitrary units.

In conclusion, by using a large cohort of convalescents and several antibody quantification methods, we found no evidence to confirm some earlier reports that $A B O$ blood group type impacts the quantity of anti-SARS-CoV-2 antibodies in COVID-19 convalescent donors of hyperimmune plasma.

\section{Declarations}

Ethics

The study was approved by the national Medical Ethics Committee of Republic of Slovenia (0120-241/2020-8, from 18.6.2020) and conducted from June 2020 to August 2021.

\section{Funding}

This work was partly supported by the research program P3-0371 of the Slovenian Research Agency. Samples were kindly provided by the team of Emergency Support Instrument (ESI) Convalescent COVID-19 Plasma project, European Commission, Directorate - General for Health and Food Safety, Health Systems, Medical Products and Innovation (01.09 2020 31.08.2021). 


\section{Authorship}

\section{Contribution:}

$K \check{Z}$ collected, verified, and analyzed the data, managed the software, and wrote the draft manuscript. MJK and KJ collected data, investigated methodology, wrote the draft, and revised the manuscript. PM acquired the funding, supervised, and administered the project, and critically reviewed the manuscript. URP analyzed the samples and wrote the manuscript. PR acquired the funding, conceptualized, designed, and supervised the study, and wrote the manuscript.

All authors read and approved the final manuscript.

Conflict-of-interest disclosure: The authors declare no competing financial interests.

\section{Acknowledgements:}

Authors would like to thank Maja Černilec and Marjana Šprohar for help with collecting and distributing the samples; Petra Jovanovič and Sonja Vuletić for help with analyzing the samples, to all personnel at Blood Transfusion Centre of Slovenia for their contribution to the collection of CCP donations, and to Stephen Minger for critical reading of the letter.

Correspondence: Primož Rožman, Blood Transfusion Centre of Slovenia, Šlajmerjeva 6, 1000 Ljubljana, Slovenia; e-mail: primoz.rozman@ztm.si

\section{References}

1. Li J, Wang X, Chen J, Cai Y, Deng A, Yang M. Association between ABO blood groups and risk of SARS-CoV-2 pneumonia. Br J Haematol. Jul 2020;190(1):24-27. doi:10.1111/bjh.16797

2. Zhao J, Yang Y, Huang H, et al. Relationship Between the ABO Blood Group and the Coronavirus Disease 2019 (COVID-19) Susceptibility. Clin Infect Dis. Jul 15 2021;73(2):328331. doi:10.1093/cid/ciaa1150

3. Coto E, Albaiceta GM, Clemente MG, Gómez J. Lack of association between SNPsrs8176719 (O blood group) and COVID-19: Data from Spanish age matched patients and controls. Transfusion. Feb 2021;61(2):654-656. doi:10.1111/trf.16206

4. Levi JE, Telles PR, Scrivani H, Campana G. Lack of association between ABO blood groups and susceptibility to SARS-CoV-2 infection. Vox Sang. Feb 2021;116(2):251-252. doi:10.1111/vox.13015

5. Szymanski J, Mohrmann L, Carter J, et al. ABO blood type association with SARS-CoV-2 infection mortality: A single-center population in New York City. Transfusion. Apr 2021;61(4):1064-1070. doi:10.1111/trf.16339

6. Ray JG, Schull MJ, Vermeulen MJ, Park AL. Association Between ABO and Rh Blood Groups and SARS-CoV-2 Infection or Severe COVID-19 IIIness : A Population-Based Cohort Study. Ann Intern Med. Mar 2021;174(3):308-315. doi:10.7326/m20-4511 
medRxiv preprint doi: https://doi.org/10.1101/2021.10.19.21265195; this version posted October 26, 2021. The copyright holder for this preprint (which was not certified by peer review) is the author/funder, who has granted medRxiv a license to display the preprint in perpetuity.

It is made available under a CC-BY-ND 4.0 International license .

7. Liu N, Zhang $T$, Ma L, et al. The impact of ABO blood group on COVID-19 infection risk and mortality: A systematic review and meta-analysis. Blood Rev. Jul 2021;48:100785. doi:10.1016/j.blre.2020.100785

8. Zhang Y, Garner R, Salehi S, La Rocca M, Duncan D. Association between ABO blood types and coronavirus disease 2019 (COVID-19), genetic associations, and underlying molecular mechanisms: a literature review of 23 studies. Ann Hematol. May 2021;100(5):1123-1132. doi:10.1007/s00277-021-04489-w

9. Golinelli D. On the association between the ABO blood group and COVID-19 susceptibility. Blood Transfus. Jan 2021;19(1):89-90. doi:10.2450/2020.0356-20

10. Goel R, Bloch EM, Pirenne F, et al. ABO blood group and COVID-19: a review on behalf of the ISBT COVID-19 Working Group. Vox Sang. Sep 2021;116(8):849-861.

doi:10.1111/vox.13076

11. Joyner M, Wright RS, Fairweather D, et al. Early Safety Indicators of COVID-19 Convalescent Plasma in 5,000 Patients. medRxiv. May 14 2020;doi:10.1101/2020.05.12.20099879

12. Casadevall A, Pirofski LA. The convalescent sera option for containing COVID-19. J Clin Invest. Apr 1 2020;130(4):1545-1548. doi:10.1172/JCl138003

13. FDA. Updated Evidence to Support the Emergency Use of COVID-19 Convalescent Plasma - as of 9/23/2020. . Accessed 9/23/2020, 2020. https://www.fda.gov/media/142386/download

14. Anon. An EU programme of COVID-19 convalescent plasma collection and transfusion. Guidance on collection, testing, processing, storage, distribution and monitored use 2020:8. 23.6.2020.

https://ec.europa.eu/health/sites/health/files/blood tissues organs/docs/guidance plas ma covid19 en.pdf

15. Hinton DM. Authorization of the emergency use of COVID-19 convalescent plasma for treatment of hospitalized patients with COVID-19. August 23 2020. Washington,DC2020.

16. Li L, Tong X, Chen H, et al. Characteristics and serological patterns of COVID-19 convalescent plasma donors: optimal donors and timing of donation. Transfusion. Aug 2020;60(8):1765-1772. doi:10.1111/trf.15918

17. Körper S, Jahrsdörfer B, Corman VM, et al. Donors for SARS-CoV-2 Convalescent Plasma for a Controlled Clinical Trial: Donor Characteristics, Content and Time Course of SARSCoV-2 Neutralizing Antibodies. Transfus Med Hemother. May 2021;48(3):137-147. doi:10.1159/000515610

18. Wendel S, Fontão-Wendel R, Fachini R, et al. A longitudinal study of convalescent plasma (CCP) donors and correlation of $A B O$ group, initial neutralizing antibodies ( $\mathrm{nAb}$ ), and body mass index (BMI) with nAb and anti-nucleocapsid (NP) SARS-CoV-2 antibody kinetics: Proposals for better quality of CCP collections. Transfusion. May 2021;61(5):1447-1460. doi:10.1111/trf.16323

19. Madariaga MLL, Guthmiller JJ, Schrantz S, et al. Clinical predictors of donor antibody titre and correlation with recipient antibody response in a COVID-19 convalescent plasma clinical trial. J Intern Med. Apr 2021;289(4):559-573. doi:10.1111/joim.13185 
medRxiv preprint doi: https://doi.org/10.1101/2021.10.19.21265195; this version posted October 26, 2021. The copyright holder for this preprint

(which was not certified by peer review) is the author/funder, who has granted medRxiv a license to display the preprint in perpetuity.

It is made available under a CC-BY-ND 4.0 International license.

20. de Freitas Dutra V, Bonet-Bub C, Yokoyama APH, et al. Anti-A and SARS-CoV-2: an intriguing association. Vox Sang. May 2021;116(5):557-563. doi:10.1111/vox.13044

21. Bloch EM, Patel EU, Marshall C, et al. ABO blood group and SARS-CoV-2 antibody response in a convalescent donor population. Vox Sang. Aug 2021;116(7):766-773. doi:10.1111/vox.13070

22. Hayes C, Rubenstein W, Gibb D, Klapper E, Tanaka J, Pepkowitz S. Blood group O convalescent plasma donations have significantly lower levels of SARS-CoV-2 IgG antibodies compared to blood group A donations. Transfusion. Aug 2021;61(8):22452249. doi:10.1111/trf.16524

23. Vidan-Jeras BL, N.; Mali,P.; Bricl,I. Life flows because of you... The report on the transfusion activity in Slovenia 2015 - 2016. A special publication on the 25th jubilee of the Slovenia Donor - the registry of the unrelated HSC donors. Ljubljana: Blood Transfusion Centre of Slovenia; 2017. p. 39.

24. Nguyen $D$, Simmonds $P$, Steenhuis $M$, et al. SARS-CoV-2 neutralising antibody testing in Europe: towards harmonisation of neutralising antibody titres for better use of convalescent plasma and comparability of trial data. Euro Surveill. Jul 2021;26(27)doi:10.2807/1560-7917.ES.2021.26.27.2100568 